\title{
Fenolik Total, Kandungan Flavonoid, dan Aktivitas Antioksidan Ekstrak Etanol Daun Mareme (Glochidion arborescens Blume.)
}

(Total phenolic content, flavonoid concentration and antioxidant activity in Glochidion arborescens leaves extract)

\author{
$\underline{\text { Indra }}^{* 1}$, Novianti Nurmalasari ${ }^{1}$, \& Meti Kusmiati $^{2}$ \\ ${ }^{1}$ Program Studi Farmasi Sekolah Tinggi IImu Kesehatan Bakti Tunas Husada Tasikmalaya, Jl. Ariodillah III No.22A, Kota \\ Palembang \\ ${ }^{2}$ Program Studi Teknologi Laboratorium Medik Bakti Tunas Husada Tasikmalaya, Jl. Ariodillah III No.22A, Kota \\ Palembang
}

\begin{abstract}
Glochidion arborescens Blume is often consumed by the people, especially the Sundanese as a vegetable dish. Several studies have shown that the genus Glochidion has potential as a medicinal plant. This research aimed to determine the total phenolic content, total flavonoid and antioxidant activity of Glochidion arborescens leaves. A dry powder of Glochidion arborescens leaves extracted by reflux process using ethanol-water $70 \% \mathrm{v} / \mathrm{v}$. A total phenolic essay is determined by the method of Folin-Chiocalteu reagent using gallic acid as a reference. AlCl3 reagent is used to analyse the flavonoid content by comparing with quercetin. The antioxidant activity of the extract was determined by radical scavenging assay using DPPH (2,2-diphenyl-1picrylhydrazyl) radical. Phytochemical screening of Glochidion arborescens leaves indicated the presence of flavonoids, tannins, polyphenols, monoterpenoids-sesquiterpenes, saponins, and quinones. The total phenolic content of ethanol extract of Glochidion arborescens leaves at $33.32 \pm 0.25 \mathrm{mg}$ Gallic Acid Equivalent (GAE)/g extract and total flavonoid content at $3.02 \pm 0.003 \mathrm{mg}$ quercetin equivalent (QE)/g extract. Antioxidant activity by DPPH method obtained IC50 ethanol extract of Glochidion arborescens leaves of $5.5 \mu \mathrm{g} / \mathrm{mL}$, and IC50 value of vitamin C was $3.34 \mu \mathrm{g} / \mathrm{mL}$. Based on these results Glochidion arborescens leaves have the potential to be developed into medicinal plants to prevent or treat diseases caused by oxidative stress.
\end{abstract}

Keywords: antioxidant; DPPH; Glochidion arborescens; leaves.

ABSTRAK: Daun mareme (Glochidion arborescens Blume.) sering dikonsumsi oleh masyarakat khususnya suku sunda sebagai lalapan. Beberapa penelitian menunjukkan bahwa genus Glochidion berpotensi untuk dijadikan sebagai tanaman obat. Penelitian ini bertujuan untuk menentukan kandungan fenolik total, flavonoid total, dan aktivitas antioksidan ekstrak etanol-air daun mareme. Serbuk kering daun mareme diekstraksi dengan proses refluks menggunakan pelarut etanol-air $70 \% \mathrm{v} / \mathrm{v}$. Ekstrak kemudian dipekatkan dengan rotary evaporator dan penapisan fitokimia. Penetapan kadar fenolik total menggunakan pereaksi Folin-Ciocalteu dengan pembanding asam galat. Kandungan flavonoid total ditetapkan dengan pembanding kuersetin menggunakan pereaksi AICl3. Aktivitas antioksidan ditentukan oleh uji peredaman radikal 2,2-difenil-1-pikrilhidrazil (DPPH) dengan vitamin $\mathrm{C}$ sebagai pembanding. Hasil penafisan fitokimia menunjukkan bahwa daun mareme mengandung senyawa flavonoid, tanin, polifenol, monoterpenoid-seskuiterpen, saponin dan kuinon. Kadar fenolik total ekstrak daun mareme sebesar 33,32 $\pm 0,25$ mg Gallic Acid Equivalent (GAE)/g ekstrak, sedangkan kadar flavonoid total sebesar 3,02 $\pm 0,003 \mathrm{mg}$ Quercetin Equivalent (QE)/g ekstrak. Hasil uji aktivitas antioksidan dengan metode DPPH diperoleh nilai IC50 ekstrak etanol daun mareme sebesar 5,5 $\mu \mathrm{g} / \mathrm{mL}$, dan nilai IC50 pembanding vitamin C sebesar 3,34 $\mu \mathrm{g} / \mathrm{mL}$. Berdasarkan hasil ini daun mareme memiliki potensi untuk dikembangkan menjadi tanaman obat untuk mencegah atau mengobati penyakit yang disebabkan oleh stress oksidatif

Kata kunci: antioxidant; DPPH; Glochidion arborescens; daun.

\section{Pendahuluan}

Terdapat sekitar delapan ribu tumbuhan yang mengandung senyawa fenolik dan setengah dari jumlah tersebut adalah flavonoid. Senyawa Fenolik merupakan golongan fitokimia terbesar pada tumbuhan yang memiliki aktivitas sebagai antioksidan [1]. Flavonoid memiliki aktivitas antioksidan sehingga dapat mencegah penyakit kardiovaskular, kanker dan penyakit degenerasi komponen sel lainnya yang disebabkan oleh usia. Antioksidan yang diperoleh dari tanaman memiliki manfaat yang

\section{Article history}

Received: 25 Okt 2019 Accepted: 03 Nov 2019 Published: 30 Des 2019

Access this article

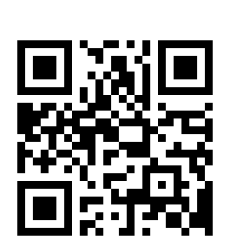


lebih besar dibandingkan dengan sintetik hal ini disebabkan karena sifat alami dari antioksidan tersebut [2]. Berbagai macam penyakit pada manusia seperti aterosklerosis, peradangan sendi, penyakit Alzheimer dan kanker dapat disebabkan oleh peningkatan konsentrasi radikal bebas. Radikal bebas dapat bersumber dari metabolisme normal atau induksi oleh radiasi UV maupun paparan berbagai polutan [3].

Daun Mareme (Glochidion arborescens Blume.) sering dikonsumsi oleh masyarakat khususnya suku Sunda (Indonesia) sebagai lalapan. Genus Glochidion merupakan keluarga tanaman Euphorbiaceae yang tersebar di Asia seperti Vietnam, Thailand, Malaysia, Indonesia dan umumnya digunakan sebagai obat tradisional untuk pengobatan influenza, dispepsia, disentri dan radang sendi [4]. Beberapa penelitian telah dilakukan mengenai aktivitas tanaman genus Glocbidion diantaranya adalah Glochidion Daltonii sebagai antiinflamasi dan antioksidan [5], Glochidion ellipticum sebagai antioksidan dan antelmintik [6,7], Glochidion bypoleucum sebagai antioksidan dan telah berhasil mengisolasi 5 senyawa polifenol [8].

Berdasarkan hasil penelitian tersebut dapat diketahui bahwa tanaman genus Glochidion memiliki potensi untuk dikembangkan untuk pengobatan dan diperlukan eksplorasi lebih lanjut untuk spesies yang berbeda yang belum pernah diteliti. Oleh sebab itu peneliti tertarik untuk menentukan kandungan total fenolik dan flavonoid total serta aktivitas antioksidan ekstrak etanol-air daun mareme (Glochidion arborescens Blume) melalui uji peredaman radikal 2,2-difenil-1-pikrilhidrazil (DPPH).

\section{Metode Penelitian}

\section{Alat dan Bahan}

Alat-alat yang digunakan dalam penelitian ini antara lain spektrofotometer UV-Vis (shimadzu 1601, Jepang), oven (Memmert, Jerman), Moisture balance (Ohaus, Amerika), desikator, pH meter (Eutech Instrument, Singapura), magnetic stirrer (Ika, Jerman), hot plate (Thermo, Jepang), desikator, timbangan analitik (Mettler Toledo, Amerika), alat-alat gelas.

Bahan yang digunakan dalam penelitian adalah daun mareme (Glochidion arborescens) diperoleh dari daerah Cilolohan, Kecamatan Tawang, Kota Tasikmalaya, etanol, amonium hidroksida, asam asetat, asam klorida, asam sulfat, kloroform teknis (Brataco Chemika, Indonesia), alumunium klorida (Merck, Jerman), radikal DPPH (Sigma Aldrich, Singapura), reagen Folin-Ciocalteu (Sigma Aldrich, Singapura), kuersetin (Sigma Aldrich, Singapura), asam galat (Sigma Aldrich, Singapura), metanol (Merck, Jerman), asam askorbat (Sigma Aldrich, Singapura).
Cara Kerja

Determinasi

Daun mareme dideterminasi di Herbarium Bandung, Program Studi Biologi, Universitas Padjajaran Bandung. Determinasi dilakukan untuk memastikan spesies tumbuhan yang digunakan dalam penelitian.

\section{Ekstraksi Simplisia}

Ekstrak kental etanol daun mareme dibuat dengan menggunakan metode refluks [9]. Serbuk simplisia daun mareme ditimbang $200 \mathrm{gr}$, dimasukan ke dalam labu alas bulat rendam menggunakan pelarut etanol-air 70\% (v/v). Setiap 4 jam dilakukan pergantian pelarut baru dan dilanjutkan dengan ekstraksi sebanyak 3 kali. Hasil berupa ekstrak kemudian dipekatkan menggunakan rotary evaporator pada suhu $60 \mathrm{oC}$ sampai diperoleh massa ekstrak yang kental dan dihitung rendemennya terhadap bobot simplisia awal.

Penapisan Fitokimia

Fitokimia pada ekstrak ditapis berdasarkan metode standar [10], untuk mengetahui adanya golongan senyawa alkaloid, monoterpenoid, seskuiterpenoid, flavonoid, tannin, polifenol, triterpenoid, steroid, kuinon, dan saponin.

Analisis Kuantitatif Fenolik Total

Kandungan fenolik total pada daun mareme ditentukan dengan menggunakan metode spektrofotometer [11]. Sebanyak 1,0 mL sampel ditambahkan dengan 5,0 $\mathrm{mL}$ pereaksi Folin-Ciocalteu yang telah diencerkan dengan air $(1: 10 \mathrm{v} / \mathrm{v})$ dan $4 \mathrm{~mL} \mathrm{Na} \mathrm{CO}_{3} 1 \mathrm{M}$. Setelah diinkubasi selama 15 menit kemudian diukur absorbansi pada panjang gelombang $711 \mathrm{~nm}$. Pembuatan kurva baku asam galat dibuat dengan seri konsentrasi 18; 20; 23; 25; 27; $30 \mu \mathrm{g} /$ $\mathrm{mL}$. Kandungan fenolik total dinyatakan sebagai $\mathrm{mg}$ ekivalen asam galat tiap 1 gr berat ekstrak. Pengukuran sampel direplikasi sebanyak 3 kali.

\section{Analisis Kuantitatif Flavonoid Total}

Kandungan flavonoid total ditentukan dengan metode pembentukan kompleks menggunakan alumunium klorida dan dianalisis menggunakan spektrofotometri [12]. Ekstrak dimasukkan dalam labu takar $10 \mathrm{~mL}$, ditambah $4 \mathrm{ml}$ aquades dan 0,3 mL larutan $\mathrm{NaNO}_{2}$, lalu dibiarkan selama 6 menit. Setelah itu larutan ditambah dengan $0,3 \mathrm{~mL} \mathrm{AlCl3}$ 10\% dan dibiarkan selama 15 menit dan selanjutnya dibaca absorbansi pada panjang gelombang $510 \mathrm{~nm}$, terhadap blanko terdiri atas semua pereaksi yang digunakan dengan tidak disertai kuersetin atau sampel ekstrak. Pembuatan 
kurva baku kuersetin dibuat dengan seri konsentrasi 9; 10; $11 ; 12 ; 13 \mu \mathrm{g} / \mathrm{mL}$ kandungan flavonoid total dinyatakan sebagai mg ekivalen kuersetin tiap 1 gr berat ekstrak. Pengukuran sampel direplikasi sebanyak 3 kali.

\section{Pengujian Aktivitas Antioksidan}

Sampel ditimbang $50 \mathrm{mg}$ kemudian larutkan dalam metanol (500 ppm), lakukan pengenceran hingga 50 ppm kemudian buat variasi konsentrasi. Larutan tersebut kemudian ditambah dengan larutan DPPH 50 ppm dengan perbandingan volume 1:1 campuran tersebut diinkubasi selama 30 menit dan absorbansinya diukur menggunakan spektrofotometer UV-Vis pada panjang gelombang maksimum DPPH [13]. Persen inhibisi dapat dihitung dengan menggunakan :

\section{$\%$ inhibisi $=\frac{\text { A blanko }- \text { A sampel }}{\text { A blanko }} \times 100 \%$}

Konsentrasi sampel dan persen inhibisi yang diperoleh disubstitusi masing-masing pada sumbu $\mathrm{x}$ dan y pada persamaan regresi linier. Persamaan tersebut digunakan untuk menentukan nilai IC50 dari sampel dinyatakan dengan nilai y sebesar 50 dan x yang akan diperoleh sebagai IC50 [13].

\section{Hasil dan Diskusi}

\section{Ekstraksi Simplisia}

Serbuk daun mareme diekstraksi menggunakan metode refluks dengan tujuan agar metabolit sekunder pada sampel dapat tertarik sempurna, karena refluks merupakan salah satu teknik ekstraksi panas sehingga diharapkan proses penyarian terjadi secara optimal. Proses refluks dilakukan pada suhu $60 \mathrm{oC}$ untuk menjaga stabilitas dari senyawa antioksidan. Sebanyak $200 \mathrm{gr}$ serbuk simplisia serbuk kering diekstraksi menggunakan etanol 70\% menghasilkan rendemen 70,3 gr ekstrak kental (35\%). Ekstraksi metode refluks lebih efisien dibandingkan metode perkolasi atau maserasi dan membutuhkan pelarut dan waktu ekstraksi yang lebih sedikit [9]. Pelarut etanolair (70:30) digunakan pada penelitian ini karena pelarut campur tersebut dengan adanya air maka semakin banyak pelarut polar dalam daun mareme yang dapat berdifusi kedalam pelarut dan yang lebih penting adalah tidak toksik bagi tubuh manusia [14].

\section{Uji Fitokimia}

Hasil uji fitokimia simplisia daun mareme menunjukkan kandungan senyawa golongan flavonoid, polifenol, tanin, monoterpenoid, seskuiterpenoid, kuinon, dan saponin (Tabel 1). Golongan senyawa flavonoid dan polifenol diketahui mempunyai aktivitas antioksidan [1517]. Berdasarkan hasil pengujian fitokimia dapat diketahui bahwa metode ekstraksi refluks dapat mengekstraksi kandungan senyawa fitokimia yang memiliki aktivitas antioksidan. Hasil ini sesuai dengan penelitian yang dilakukan oleh Ghasemzadeh dan Jaafar yang menunjukkan bahwa ekstrak tanaman pandan (Pandanus amaryllifolius Roxb.) dengan metode refluks memiliki kandungan senyawa fenolik dan flavonoid yang tinggi [18].

Tabel 1. Hasil Uji Fitokimia Daun Mareme (Glochidion arborescens Blume.)

\begin{tabular}{clc}
\hline No & \multicolumn{1}{c}{$\begin{array}{c}\text { Golongan Senyawa Kimia } \\
\text { yang diperiksa }\end{array}$} & $\begin{array}{c}\text { Hasil } \\
\text { Pengamatan }\end{array}$ \\
\hline 1 & Alkaloid & - \\
2 & Flavonoid & + \\
3 & Polifenol & + \\
4 & Tanin & + \\
5 & Mono dan seskuiterpen & + \\
6 & Steroid dan triterpenoid & - \\
7 & Kuinon & + \\
8 & Saponin & + \\
\hline
\end{tabular}

Keterangan : (+) Terdeteksi, (-) Tidak terdeteksi

Analisis Kuantitatif Fenolik Total

Kandungan fenolik total daun mareme menggunakan reagen Folin-Ciocalteu kemudian dianalisis dengan spektrofotometer UV-Vis. Senyawa fenolik akan bereaksi dengan reagen Folin-Ciocalteu dan membentuk senyawa kompleks berwarna biru dengan intensitas warna sesuai dengan kandungan senyawa fenolik yang ada. Larutan standar yang digunakan adalah asam galat yang merupakan senyawa fenolik turunan asam hidroksibenzoat yang stabil dan sederhana [19]. Hasil pengukuran larutan standar asam galat diperoleh kurva kalibrasi dengan persamaan regresi $y=0,0132 x-0,0319$ dengan nilai $R$ sebesar 0,9978 (Gambar 1).

Kandungan fenolik total dalam ekstrak tergantung pada polaritas pelarut yang digunakan dalam ekstraksi. Kelarutan tinggi senyawa fenol dalam pelarut polar memberikan konsentrasi tinggi pada ekstrak yang diperoleh dengan menggunakan pelarut polar pada saat ekstraksi [20]. Kadar fenolik total dalam ekstrak daun mareme dihitung dengan menggunakan persamaan regresi linier. Kandungan fenolik total dinyatakan sebagai ekuivalen asam galat atau Gallic Acid Equivalent (GAE) karena belum 
diketahui struktur kimia senyawa fenolik yang terdapat pada ekstrak.

Berdasarkan hasil analisis, kandungan fenolik total dalam ekstrak etanol daun mareme sebesar 33,32 \pm 0,25 mg GAE/g, artinya dalam setiap gram ekstrak setara dengan 33,32 $\mathrm{mg}$ asam galat (Tabel 2). Penelitian yang dilakukan oleh Mongkolsilp dkk terhadap lima tanaman obat Thailand mengungkapkan bahwa semakin tinggi kandungan fenolik total maka semakin tinggi pula aktivitas peredaman radikal bebas DPPH [21].

Tabel 2. Hasil Pengukuran Kadar Fenolik Total Ekstrak Daun Mareme (Glochidion arborescens Blume.)

\begin{tabular}{|c|c|}
\hline Replikasi & $\begin{array}{c}\text { Kandungan Fenolik Total } \\
\text { (mg GAE/g ekstrak) }\end{array}$ \\
\hline 1 & 33,134 \\
\hline 2 & 33,229 \\
\hline 3 & 33,608 \\
\hline$X \pm S D$ & $33,324 \pm 0,250$ \\
\hline
\end{tabular}

Senyawa fenolik pada beberapa penelitian mempunyai aktivitas antioksidan karena kemampuan meredam oksigen reaktif, hal ini dikarenakan pada cincin aromatik terdapat beberapa gugus hidroksi yang berperan sebagai donor hidrogen [22].

\section{Analisis Kuantitatif Flavonoid Total}

Kandungan flavonoid total ekstrak etanol daun mareme ditentukan dengan metode pembentukan kompleks antara aluminium klorida dengan gugus keto pada atom C-4 dan gugus hidroksi pada atom C-3 atau C-5 yang bertetangga dari golongan flavon dan flavonol.

Kuersetin digunakan sebagai standar untuk penetapan kadar flavonoid karena kuersetin termasuk golongan flavonol yang memiliki gugus keto pada atom C-4 dan juga gugus hidroksil pada atom C-3 dan C-5 yang bertetangga [23].

Hasil pengukuran absorbansi pada beberapa konsentrasi yaitu 9; 10;11;12; $13 \mu \mathrm{g} / \mathrm{mL}$ diperoleh hubungan yang linier antara absorbansi dengan konsentrasi sebesar 0,9986. Dari hasil perhitungan, diperoleh nilai intersep sebesar 0,6669 dan nilai slope sebesar 0,1079 sehingga diperoleh persamaan kurva baku y $=0,1079$ $\mathrm{x}-0,6669$. Persamaan tersebut digunakan sebagai pembanding dalam analisis kuantitatif pada pengukuran kandungan flavonoid kuersetin terhadap ekstrak etanol daun mareme (Gambar 2)

Flavonoid total pada ekstrak etanol daun mareme diperoleh dengan cara memasukkan nilai absorbansi pada kurva standar kuersetin sehingga berdasarkan perhitungan diperoleh kadar flavonoid total rata-rata ekstrak etanol daun mareme sebesar 3,02 \pm 0,003 $\mathrm{mg} \mathrm{EQ/g}$ (Tabel 3), artinya dalam setiap gram ekstrak setara dengan 3,02 $\mathrm{mg}$ kuersetin. Asupan flavonoid diatas $100 \mathrm{mg}$ memiliki aktivitas antioksidan setara dengan 2-3 mg $\beta$-karoten, 70$100 \mathrm{mg}$ vitamin C, 7-10 mg Vitamin E [24]. Data ini sesuai dengan beberapa laporan penelitian yang mengungkapkan bahwa beberapa flavonoid telah ditemukan memiliki aktivitas sebagai antiinflamasi [25], antiplatelet [26] dan antidiabetes [27].

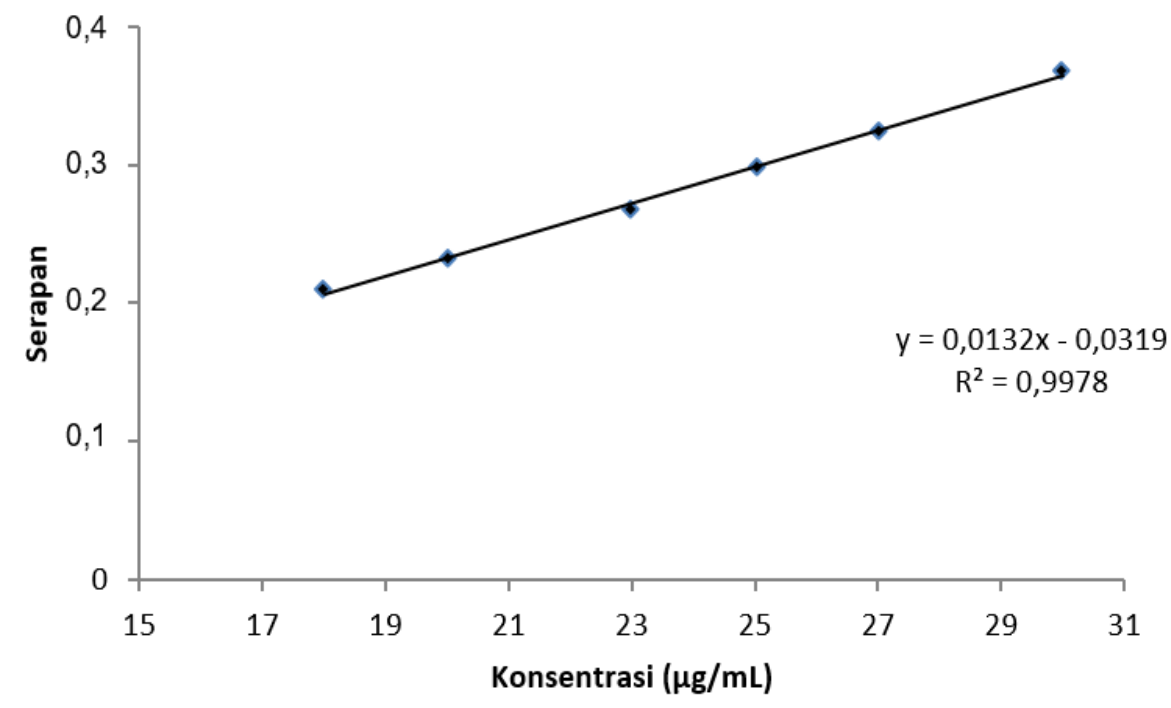

Gambar 1. Kurva kalibrasi asam galat pada panjang gelombang $711 \mathrm{~nm}$ 


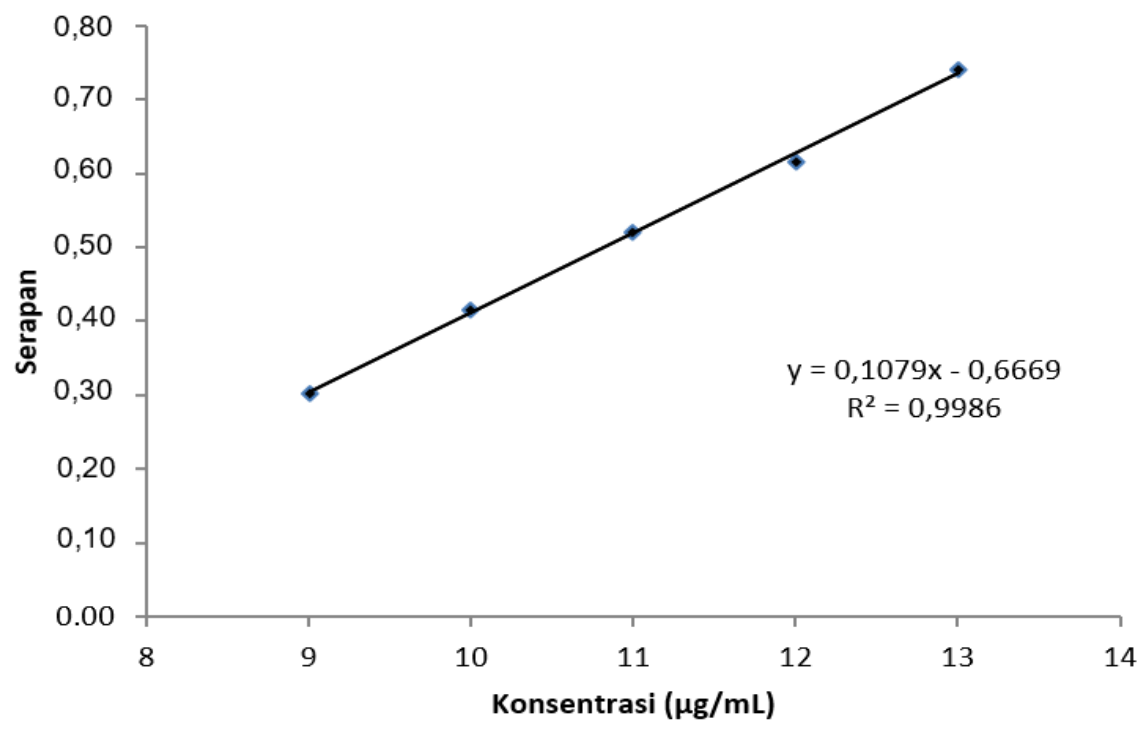

Gambar 2. Kurva kalibrasi kuersetin pada panjang gelombang $510 \mathrm{~nm}$

Tabel 3. Hasil Pengukuran Kadar Flavonoid Total Ekstrak Daun Mareme (Glochidion arborescens Blume.)

\begin{tabular}{|c|c|}
\hline Replikasi & $\begin{array}{c}\text { Kandungan Flavonoid Total } \\
\text { (mg QE/g ekstrak) }\end{array}$ \\
\hline 1 & 3,021 \\
\hline 2 & 3,024 \\
\hline 3 & 3,027 \\
\hline$X \pm S D$ & $3,024 \pm 0,003$ \\
\hline
\end{tabular}

Uji Aktivitas Antioksidan

Metode DPPH merupakan metode yang umum digunakan untuk pengujian aktivitas antioksidan pada bahan alam atau ekstrak tanaman[28]. Aktivitas antioksidan diukur dengan menghitung berkurangnya intensitas cahaya ungu DPPH yang setara dengan pengurangan konsentrasi DPPH. Peredaman DPPH disebabkan karena reaksi molekul difenil pikeril hidrazil (DPPH) dengan atom hidrogen yang dilepaskan oleh molekul komponen sampel sehingga terbentuk senyawa difenil pikril hidrazin dan menyebabkan terjadinya pengurangan warna DPPH dari ungu menjadi kuning [29].

Hasil uji aktivitas antioksidan dari ekstrak etanol daun mareme ditunjukkan sebagai persentase penghambatan radikal bebas DPPH dan dibandingkan dengan aktivitas antioksidan vitamin C (Tabel 4). Berdasarkan nilai \% inhibisi sampel dan vitamin $\mathrm{C}$ pada berbagai konsentrasi maka dapat diperoleh nilai IC50. Semakin kecil nilai IC50, semakin tinggi aktivitas antioksidan pada sampel tersebut [30]. Hasil pengujian menunjukkan bahwa vitamin C sebagai standar antioksidan sintetik memiliki IC50 3,34 $\mu \mathrm{g} / \mathrm{mL}$ dan ekstrak etanol daun mareme memiliki IC50 sebesar 5,62 $\mu \mathrm{g} / \mathrm{mL}$, artinya pada konsentrasi 5,62 $\mu \mathrm{g} / \mathrm{mL}$ ekstrak dapat menghambat 50\% radikal bebas (DPPH).

Tabel 4. Hasil Uji Antioksidan Ekstrak Etanol Daun Mareme

\begin{tabular}{|c|c|c|c|}
\hline Sampel & $\begin{array}{c}\text { Konsentrasi } \\
(\mu \mathrm{g} / \mathrm{mL})\end{array}$ & \% Inhibisi & $\begin{array}{c}\mathrm{IC50} \\
(\mu \mathrm{g} / \mathrm{mL})\end{array}$ \\
\hline \multirow{6}{*}{$\begin{array}{l}\text { Vitamin C } \\
\text { (Asam Askorbat) }\end{array}$} & 1 & 31,499 & 3,3380 \\
\hline & 2 & 38,514 & \\
\hline & 3 & 47,042 & \\
\hline & 4 & 54,608 & \\
\hline & 5 & 64,374 & \\
\hline & 6 & 71,939 & \\
\hline \multirow{6}{*}{$\begin{array}{l}\text { Ekstrak Daun } \\
\text { Mareme }\end{array}$} & 2 & 11,374 & 5,6212 \\
\hline & 3 & 24,961 & \\
\hline & 4 & 34,439 & \\
\hline & 5 & 42,180 & \\
\hline & 6 & 52,765 & \\
\hline & 7 & 65,087 & \\
\hline
\end{tabular}

Pada pengujian penapisan fitokimia diketahui bahwa ekstrak etanol daun mareme mengandung berbagai senyawa metabolit sekunder termasuk polifenol (tanin dan flavonoid). Tumbuhan yang mengandung polifenol merupakan sumber antioksidan penting karena memiliki struktur kimia yang ideal untuk meredam radikal bebas. Sejumlah eksperimen secara meyakinkan, menunjukkan 
potensi antioksidan dalam mengurangi resiko terhadap berbagai penyakit akut dan kronis seperti kanker, penyakit jantung dan stroke dengan cara meredam senyawa radikal bebas yang terlibat dalam patogenesis berbagai penyakit [31].

Pada percobaan ini diketahui bahwa ekstrak daun mareme tinggi kandungan polifenol (33,32 mg GAE/g), flavonoid (3,02 mgQE/g), dan memilikiaktivitas peredaman radikal bebas yang baik. Aktivitas antioksidan yang baik pada ekstrak dapat disebabkan oleh adanya kandungan fenolik dan flavonoid, hal ini sesuai dengan penelitian yang telah dilakukan oleh Feng-Lin dkk yang menunjukkan bahwa terdapat korelasi yang linier antara kandungan fenolik dan flavonoid terhadap aktivitas antioksidan [32]. Hasil tersebut sesuai dengan percobaan Natthine et al, 2014 pada ekstrak metanol Glochidion bypolacum (Miq) telah berhasil melakukan isolasi 5 senyawa polifenol yaitu metil galat, asam galat, epigenin-8-C- $\beta$-D-glukopiranosida (vitexin), luteulin-8-C- $\beta$-D-glukopiranosida (orientin) dan luteulin-6-C- $\beta$-D-glukopiranosida (isoorientin). Pada percobaan tersebut diketahui bahwa selain vitexin, senyawa polifenol pada ekstrak metanol Glochidion bypolacum (Miq) memiliki aktivitas antioksidan yang tinggi [8].

\section{Kesimpulan}

Berdasarkan hasil penelitian dapat disimpulkan bahwa ekstrak etanol daun mareme (Glochidion arborescens Blume.) berpotensi sebagai sumber antioksidan alami. Ekstrak daun mareme memiliki kandungan polifenol total sebesar 33,32 mg GAE/g dan flavonoid total 3,02 mg QE/g. Hasil uji peredaman radikal bebas (DPPH) diperoleh IC50 sebesar 5,62 $\mu \mathrm{g} / \mathrm{mL}$ dan ini menunjukkan nilai IC50 yang lebih besar dibandingkan dengan vitamin $\mathrm{C}(3,34 \mu \mathrm{g} / \mathrm{mL})$.

\section{Ucapan Terimakasih}

Penelitian ini dilaksanakan di Program Studi Farmasi STIKes Bakti Tunas Husada dan dibiayai oleh Hibah Penelitian Dosen Pemula dari DP2M DIKTI Tahun Anggaran 2018.

\section{Referensi}

[1] Sulaiman CT, Sadashiva CT, George S, Goplakrishnan VK, Balachandran I. Chromatographic Studies and in vitro Screening for Acetyl Cholinesterase Inhibition and Antioxidant Activity of three Acacia Species from South India. Anal Chem Lett. 2013 Jul;3(2):1118.

[2] Rohman A, S R, N Y, W.R S, R U, W M. Antioxidant activity, total phenolic, and total flavonoid of extracts and fractions of red fruit (Pandanus conoideus Lam). Int Food Res J. 2010;17:97-106.
[3] Stankovi MS. Total Phenolic Content, Flavonoid Concentration And Antioxidant Activity Of Marrubium peregrinum L. Extracts. Kragujev J Sci. 2011;33:63-72.

[4] Thang TD, Kuo P-C, Yu C-S, Shen Y-C, Hoa LTM, Van Thanh T, et al. Chemical constituents of the leaves of Glochidion obliquum and their bioactivity. Arch Pharm Res. 2011 May 6;34:383-9.

[5] Junlatat J, Sripanidkuichai B. Anti-Inflammatory And Anti-Oxidant Activities Of Glochidion Daltonii Branch Extract. J Farm Dan IImu Kefarmasian Indones. 2016;3(2):39-42.

[6] Rathod V, Rajurkar NS. Phytochemical Screening and antioxidant activity of Glochidion ellipticum. J Appl Chemsitry. 2017;6(2):21926.

[7] Sv J, Sr K. Phytochemical and Anthelmintic Investigation of Leaves of Glochidion ellipticum Linn. Eur J Exp Biol. 2017; 07(02) : 1- 3

[8] Anantachoke N, Worawan, Mangmool S, Bunyapraphatsara N. Polyphenolic Compounds and Antioxidant Activities of the Leaves of Glochidion hypoleucum. Nat Prod Commun. 2015;10(3):479-82.

[9] Zhang Q-W, Lin L-G, Ye W-C. Techniques for extraction and isolation of natural products: a comprehensive review. Chin Med. 2018;13(1):126

[10] Vinotha S, Thabrew I, Ranjani SS. Preliminary Phytochemical Screening of Different Extracts of Whole Plant of Enicostemma littorale Blume. Int J Sci. 2013;11(1):99-104.

[11] Blainski A, Lopes G, de Mello J. Application and Analysis of the Folin Ciocalteu Method for the Determination of the Total Phenolic Content from Limonium Brasiliense L. Molecules. 2013 Jun 10;18(6):6852-6865.

[12] Silva L, Pezzini B, Soares L. Spectrophotometric determination of the total flavonoid content in Ocimum basilicum L. (Lamiaceae) leaves. Pharmacogn Mag. 2015;11(41):96-102.

[13] Marxen K, Vanselow K, Lippemeier S, Hintze R, Ruser A, Hansen U-P. Determination of DPPH Radical Oxidation Caused by Methanolic Extracts of Some Microalgal Species by Linear Regression Analysis of Spectrophotometric Measurements. Sensors. 2007 Oct 3;7(10):2080-95.

[14] Azahar NF, Gani SSA, Mohd Mokhtar NF. Optimization of phenolics and flavonoids extraction conditions of Curcuma Zedoaria leaves using response surface methodology. Chem Cent J. 2017;11(1):1-10.

[15] Bao T, Wang Y, Li Y, Gowd V, Niu X, Yang H, et al. Antioxidant and antidiabetic properties of tartary buckwheat rice flavonoids after in vitro digestion. J Zhejiang Univ-Sci B. 2016 Dec;17(12):941-51.

[16] Bigoniya P, Singh K. Ulcer protective potential of standardized hesperidin, a citrus flavonoid isolated from Citrus sinensis. Rev Bras Farmacogn. 2014 May;24(3):330-40.

[17] Jazvinšćak Jembrek M, Vuković L, Puhović J, Erhardt J, Oršolić N. Neuroprotective Effect of Quercetin Against Hydrogen Peroxideinduced Oxidative Injury in P19 Neurons. J Mol Neurosci. 2012 Jun;47(2):286-99.

[18] Ghasemzadeh A, Jaafar HZE. Optimization of Reflux Conditions for Total Flavonoid and Total Phenolic Extraction and Enhanced Antioxidant Capacity in Pandan ( Pandanus amaryllifolius Roxb.) Using Response Surface Methodology. Sci World J. 2014;2014:1-10.

[19] Sari AK, Ayuchecaria N. Penetapan Kadar Fenolik Total dan Flavonoid Total Ekstrak Beras Hitam (Oryza Sativa L) Dari Kalimantan Selatan. J Ilm Ibnu Sina. 2017;2(2):327-35.

[20] Mohsen SM, Ammar ASM. Total phenolic contents and antioxidant activity of corn tassel extracts. Food Chem. 2009 Feb;112(3):595-8.

[21] Mongkolsilp S, Pongbupaki I, Sae-Lee N. Radical Scavenging Activity and Total Phenolic Content of Medicinal Plants Used in Primary Health Care. SWU J Pharm Sci. 2004;9(1):32-5.

[22] Chandra S, Khan S, Avula B, Lata H, Yang MH, ElSohly MA, et al. Assessment of Total Phenolic and Flavonoid Content, Antioxidant Properties, and Yield of Aeroponically and Conventionally Grown Leafy Vegetables and Fruit Crops: A Comparative Study. Evid Based Complement Alternat Med. 2014;2014:1-9.

[23] Kamtekar S, Keer V, Patil V. Estimation of Phenolic content, Flavonoid content, Antioxidant and Alpha amylase Inhibitory Activity of Marketed Polyherbal Formulation. J Appl Pharm Sci. 2014;4(09):0615 . 
[24] Musialik M, Kuzmicz R, Pawłowski TS, Litwinienko G. Acidity of Hydroxyl Groups: An Overlooked Influence on Antiradical Properties of Flavonoids. J Org Chem. 2009 Apr 3;74(7):2699-709.

[25] Hämäläinen $M$, Nieminen $R$, Vuorela $P$, Heinonen $M$, Moilanen E. Anti-Inflammatory Effects of Flavonoids: Genistein, Kaempferol, Quercetin, and Daidzein Inhibit STAT-1 and NF- k B Activations, Whereas Flavone, Isorhamnetin, Naringenin, and Pelargonidin Inhibit only NF- K B Activation along with Their Inhibitory Effect on iNOS Expression and NO Production in Activated Macrophages. Mediators Inflamm. 2007;2007:1-10.

[26] Guerrero JA, Lozano ML, Castillo J, Benavente-Garcia O, Vicente V, Rivera J. Flavonoids inhibit platelet function through binding to the thromboxane A2 receptor. J Thromb Haemost. 2005 Feb;3(2):36976.

[27] Djamil R, Winarti W, Zaidan S, Abdillah S. Antidiabetic Activity of Flavonoid from Binahong Leaves (Anredera cordifolia) Extract in Alloxan Induced Mice. J Pharmacogn Nat Prod. 2017; 03(02). 941951
[28] Philips A, Philip S, Arul V, Padmakeerthiga B, Renju V, Santha S, et al. Free Radical Scavenging Activity of Leaf Extracts of Indigofera Aspalathoides - An in vitro Analysis. J Pharm Sci. 2010;7.

[29] Formagio A, Volobuff C, Santiago M, Cardoso C, Vieira M, Valdevina Pereira Z. Evaluation of Antioxidant Activity, Total Flavonoids, Tannins and Phenolic Compounds in Psychotria Leaf Extracts. Antioxidants. 2014 Nov 10;3(4):745-57.

[30] Maisuthisakul P, Suttajit M, Pongsawatmanit R. Assessment of phenolic content and free radical-scavenging capacity of some Thai indigenous plants. Food Chem. 2007 Jan;100(4):1409-18.

[31] Alhakmani F, Kumar S, Khan SA. Estimation of total phenolic content, in-vitro antioxidant and anti-inflammatory activity of flowers of Moringa oleifera. Asian Pac J Trop Biomed. 2013 Aug;3(8):623-7.

[32] Song F-L, Gan R-Y, Zhang Y, Xiao Q, Kuang L, Li H-B. Total Phenolic Contents and Antioxidant Capacities of Selected Chinese Medicinal Plants. Int J Mol Sci. 2010 Jun 1;11(6):2362-72.

Copyright $\odot 2019$ The author(s). You are free to share (copy and redistribute the material in any medium or format) and adapt (remix, transform, and build upon the material for any purpose, even commercially) under the following terms: Attribution - You must give appropriate credit, provide a link to the license, and indicate if changes were made. You may do so in any reasonable manner, but not in any way that suggests the licensor endorses you or your use; ShareAlike - If you remix,
transform, or build upon the material, you must distribute your contributions under the same license as the original (https://creativecommons.org/licenses/by-sa/4.0/) 